\title{
A Consumer Complaints and Grievances Redressal System in Indian Telecom Sector
}

\author{
Mugdha Mujumdar, Sandeep Prabhu, Giri Hallur
}

\begin{abstract}
Purpose. The purpose of this research is to analyses current consumer complaints redressal mechanism adopted by Indian telecom operators and designed by telecom regulator in India.

Design/ methodology/ approach. Systematic literature review of research papers, related documents, and consultation papers published by regulator, secondary research through articles, opinions and analysis of consumer complaints registered with Telecom Service Providers (TSP). The paper is based on secondary research through literature review of related journal papers, Telecom Regulatory Authority of India (TRAI) policy documents, consultation papers, news articles along with study of complaints registered with telecom service provides.
\end{abstract}

Findings. The paper analyses the consumer complaint \& grievance redressal system in telecom sector in India and imperative need to resolve grievances in a swift and clear manner to make sure continual growth for the telecom sector. The paper specifically analyses Indian telecom diaspora about complain resolution in relation to regulatory authority, existing systems, new developments along with study/interpretation of assimilated complaints to corroborate the research findings.

Practical implications. The paper understands major issues which lead to consumer dissatisfaction about redressal complaints registered with TSPs and appeals accepted. The paper also tries to understand various consumer complaints registered add impact of recently announced telecom ombudsman because of very nascent stage. The study can help to understand what changes are required to make the redressal architecture more effective.

Originality/value. This paper furthers understanding of how TRAI functions with respect to consumer redressal. And, it sheds light on current consumer redressal architecture and what changes are required to make architecture effective and more efficient.

Keywords: consumer complaints, complaint resolution, telecom regulations, customer satisfaction, quality of services, grievance redressal.

\section{INTRODUCTION}

Telecom is important utility in economy as it is a means of taking daily transactions. It promotes organizing, influencing, activating, and exchange of information, business relationships and commercial information

Revised Manuscript Received on September 10, 2019.

Mugdha Mujumdar, research scholar at Symbiosis International (Deemed University). Research Associate at Symbiosis Institute of Telecom Management, Pune, Maharashtra, India.

Dr. Sandeep Prabhu, Associate Professor Symbiosis Institute of Telecom management, Symbiosis International (Deemed University). Marketing Management from Pune University (SPPU), Pune, Maharashtra, India.

Dr. Giri Hallur, Associate Professor at Symbiosis Institute of Telecom management, Symbiosis International (Deemed University), Pune, Maharashtra, India. mechanism in telecom sector. The paper also covers briefly no of with TSPs and their current status. However, paper is unable to

exchange. In the last two decades, the Indian telecom sector has showcased significant increase in subscriber base backed by affordable tariffs for telecom services. Currently Indian telecom market is among the top three telecom markets in the world in terms of telephone subscribers and internet subscribers. India has remarkable capabilities in telecom and software so cultivating new technologies and platforms is beneficial to reach unreached and underreached markets with efficient productivity and ensuring access to next generation technologies for every citizen. India is developing in digital way with billion cell phones and half billion internet consumers. India's data consumption of mobile is highest in the world. There is equal responsibility of service providers and authorities to protect consumer interests and handle their complaints effectively.

In India, complaint resolution gathered importance after deregulation of the telecom sector. Opening of value-added services to private investments in 1992, followed by opening up of basic telecom services to private participation through NTP1994, brought in the need to protect and promote consumer interest and competition. National Telecom Policy in 1999 further led to liberalization of cellular mobile services and cable services.

Because of significant developments in telecom, media and IT sectors and convergence of the same, Indian Government recognized the heightened role of regulation and standardization and hence in the year 1997, Telecom Regulatory Authority of India (TRAI) was established through act of parliament, TRAI Act 1997. TRAI's primary mission was protecting consumer interests and at the same time maintaining, nurturing, and balancing conditions for growth of Telecom, broadcasting, cables in such a way so that India will lead in global information society. TRAI always focus on transparency in provision of services and providing customer with adequate choice and TRAI regulations /guidelines focus on transparency in decisions affordable tariffs, and the highest quality of service, promoting competition among telecom providers in a right way.

Initially the dispute settlement function was under the purview of TRAI. Subsequently in 2000, regulator divested this responsibility to Telecom Dispute Settlement and Appellate Tribunal (TDSAT) through amendment of Act for better protection of consumer interests in the telecom sector. TDSAT authority has been responsible for resolving the issues between the government and TSPs, between TSPs

Published By: 
and between TSP and consumers. TRAI / TDSAT don't address individual complaints of consumer and TSPs are responsible to resolve individual's complaints through guidance/standard mechanism led down by regulator. Regulator conducts audits and surveys to monitor the implementation. Also, consumers have right to file a case with different consumer interests' protection forums in case TSP does not resolve complaints of consumer. However, because of paltry sum of contentious amounts, the consumer complaints to these forums have been limited. Thus, current individual grievance mechanism is in control of TSPs. Telecom subscribers can register their complaints via email/call centers/SMS to service providers for a no of service issues. Given the in adequacy of current resolution system, the regulator has recently in May 2019 announced to establish an office of Telecom Ombudsman for better resolution mechanism. The role of Ombudsman in making the better resolution system is still very initial stage and needs time to ascertain its impact.

\section{LITERATURE REVIEW}

R.U.S. Prasad in his working paper analyses Genesis of disputes and modes of dispute resolution, features of dispute resolution processes in France, Germany, Italy, the UK, the USA, Canada, Australia and Malaysia. The paper also critically factors in impact of EC directives and GATS on dispute settlement processes in EU member states. The paper finally studies Indian Telecom regulations for dispute resolution; it considers different mechanisms for regulation and dispute resolution through TDSAT. Finally, paper concludes that although the models employed in different countries have their pros and cons, an effective model encompassing strengths of those in various counties is yet to emerge and innovative practices along with tried and tested models should be deployed for better despite (Prasad, 2008).

L. Hou (2015) describes the stated contentions between competition rule and sector specific regulations in Chinese telecom market. To study this, regulatory environment and current market situation of china, competition rule and SSR, and their institutional conflicts are discussed. Regulatory obligations in telecom are asymmetric in nature which is beneficial for only leading telecom players. Convergence between broadband service and telecom service is not part of telecom regulation. Competition rule came alive after Telecom regulation. Competition rule and SSR has conflict so that it's a challenge to service provider to fulfill all regulatory aspects. "Liberalized telecom sector in China have three important forces: market mechanism, SSR and competition rules. However, scholar had doubt on the application of new competition rule in china. Conflict between sector specific regulation and competition rule is less important but question arises whether these two instruments compete or complement. Paper also discusses two regulatory approaches EU and US. It's been suggested that china should apply US approach as it is useful tool and examines Chinese circumstances. There should be balance between market force and SSR.EU approach is competing strategy and US approach is complementary approach (Hou, 2015).

Qayyum, ba Khag and Krairit (2013) investigate the combined effects of six antecedents viz; satisfaction of telecom customer, perceived service quality, customer value, churn cost, customers trust and reliability, and TSP's image with cell phone customer's loyalty and it does comparison of the separate effects as well. Customer satisfaction followed by perceived cost of switching has strong positive impact on customer loyalty, thus these needs to be given attention. Perceived quality of telecom service and its value have positive correlation with customer loyalty, they have weak impact on overall customer loyalty. Trust and corporate image do not have any significant impact. Nonetheless the resources which are used to improve quality of service and value help TSP as it increases customer perception of service and improves customer satisfaction levels.

Akroush, Mahadin: The paper examines a multi perspective model to study perceived value of customer, customer satisfaction and customer loyalty for internet subscribers. It finds that perceived value positively affects functional and technical satisfaction of customers as well as customer loyalty. Functional satisfaction affects technical satisfaction and thus leads to positive loyalty. (Akroush \& Mahadin, 2019).

Agyapong (2011) aims to understand the correlation between customer satisfaction and quality of service in Ghana's telecom market. It reveals that service quality mirrors customer satisfaction. Here study focuses on Vodafone (Ghana) and other telecom companies in Ghana. It is important for telecom firms there to improve what exactly customers want or identifying actual need of customers. Realising actual needs of customers could lead to improved network services performance which can further help marketers to make profitable branding strategies. In Ghana, telecom firms have always been criticised for poor quality of services. Deregulation policy changed old scenario of monopolistic and highly regulated telecom market of Ghana to introduction of new firms, healthy and competitive environment, service quality, reasonable prices, and social responsibility awareness by companies there. So, deregulation, competition and advancement in ICT sector creating pressure on mangers in industry to give continuous customer focussed services and quality offerings. The study reveals that quality telecom service is a competitive tool which leads to customer satisfaction (Agyapong, 2011).

For understanding Telecom regulatory aspects in Nigeria Ndukwe (2011) explains impact of telecom regulators agency on consumer protection in Nigeria. Regulatory agencies in Telecom are part of admin mechanism for strengthening position of Nigerian consumer. Objective of regulatory agency in telecom industry is to ensure consumer satisfaction. Telecom service providers have been delivering poor services to subscribers in Nigeria. Assessment of performance of telecom regulatory agencies in area of consumer protection is aimed at determining position of consumer in regulatory process. Stakeholders are government, consumers, media, and international community. Government is important stakeholders in job of telecom regulation. Its interest is to provide services as per 
desired quality, with affordability and on time in legal and orderly manner. For international investments disciplined regulatory processes are important as unpredictable regulatory environment doesn't attract investments (Ndukwe, 2011).

Biljana Angelova study reveals that customer satisfaction and service quality have strong positive connection. Satisfied customer leads to organization's growth, profitability and leads to increased frequency use, loyalty and positive word of mouth. The aim of this research study is to apply ACSI model in context of quality of services in Macedonian telecom maket. Literature says customer satisfaction is customer's attitude towards service provider. There are many factors influencing customer satisfaction friendly employees, courteous employee, knowledgeable employees, helpful employees, service quality, reasonable pricing, accurate billing. So, building customer relationship is backbone for any business (Oliver, 1981).

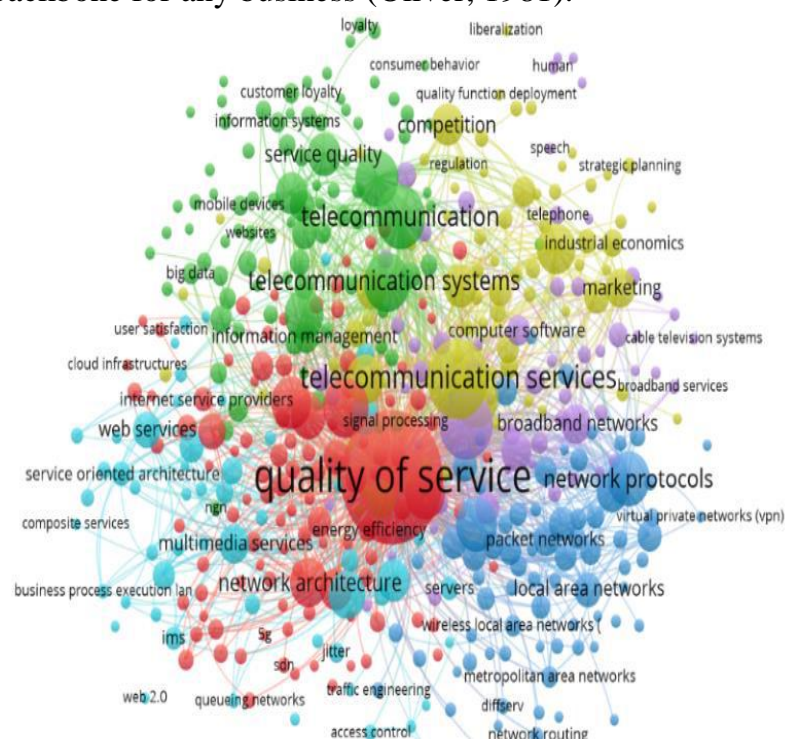

Fig.1. Literature Concept Occurrences

Fujun Lai, Mitch Griffin, Barry J. Babin (2008) study Chinese buyer behaviour. This study tests combinative model to check correlation between quality of service, image, customer satisfaction and loyalty in Chinese telecom market. Quality of service affects perception about value and image. Customers' loyalty depends upon their satisfaction and sense of value. Customer value directly or indirectly impacts customer loyalty. Chinese market is a fast growing while the US is a saturated market. Present study focuses on testing a model of customer loyalty and examines inter connections among evaluations of service quality, value perception, perception of image, satisfaction, and loyalty. (Lai, Griffin, \& Babin, 2009).

Harsandaldeep Kaur and Harmeen Soch, purpose of their study is to figure out attributes of study influencing Indian customer loyalty for mobile phone operators. Customer loyalty is driver for financial success of business. It is also driver of premium priced handset, market share and frequency of purchases. Loyal customers have strong attachment for brand. Customer loyalty concept has generated from behavioral, cognitive and composite approach. Customer satisfaction creates strong attachment and customers can be uniquely addressed leading customers as strong advocates. Trust addresses social need of customers. trust reduces uncertainty with services and minimizes transaction cost. When trust of customer is low, choice depends on cost associated with switching and profit linked for staying. Practical implication of study is that it touches CRM in telecom sector. Telecom industry has very little differentiation in services, low switching cost. Corporate image reflects the important driver of loyalty. Two limitations of the study are elimination of important variables and geographical constraint. India (Kaur \& Soch, 2018).

R. C. Upadhyaya and Vasundhara Sharma through their paper gathered subscriber feedbacks on service quality and audited records of telecom operators. The survey analysed performance of TSPs in relation to provision of services, billing performance, network performance, reliability and availability and value-added services and help/grievance handling services. Overall performance of Airtel was better than BSNL in the area surveyed. Customer satisfaction with respect to help services including grievance redressal is better for Airtel than BSNL in almost all telecom service categories - mobile, broadband etc. (Upadhyaya \& Sharma 2012)

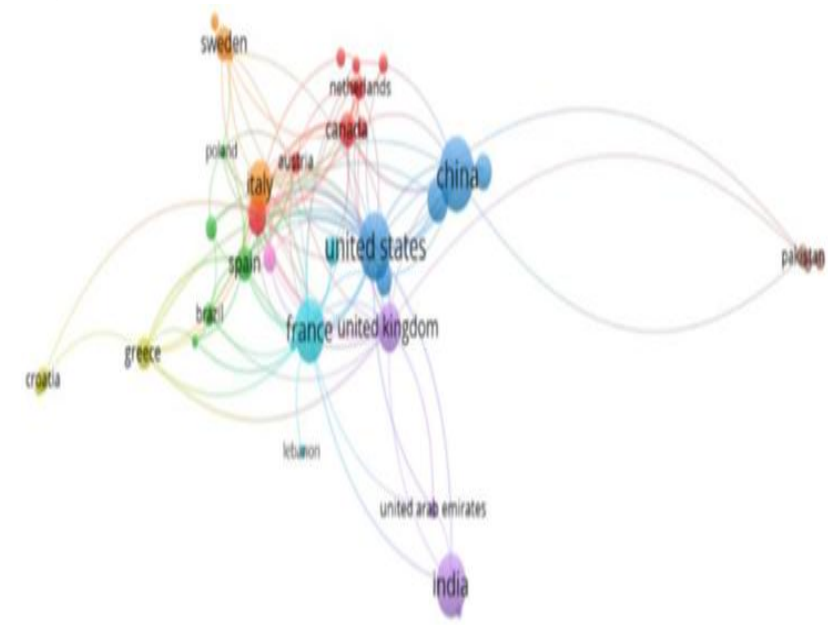

Fig.2. Literature Geographical Occurrences

The above figure shows connection between keywords and how they are linked to each other forming a mesh. Vos viewer is software tool for visualizing bibliometric network. It is used for network analysis, software tool used to analyse bibliometric data; second figure shows co-authorship and unit of analysis is countries.

\section{ROLE OF TRAI AND EXISTING COMPLAINT REDRESSAL MECHANISM}

TRAI was formed to protect interest of consumers and to promoter and ensure growth of telecom sector in India. In order to fulfill its consumer protection objective, TRAI issues regulations, directions, and orders on different consumer centric issues. Nonetheless there is immense need that consumers and consumer organisations should be made aware of the TRAI's regulations so that they can avail measures/systems put in place by TRAI. TRAI tries to reach consumers through consumer outreach program and 
publications. TRAI publishes consumer handbooks starting from enrolment of consumer and all steps that are very relevant to consumer like consumer redressal, tariff, quality of service, mobile number portability etc. Consumer education is available separately on TRAI website to understand and study regulatory aspects and consumer redressal of telecom (Telecom Regulatory Authority of India, 2018).

There are many complaints lodged in telecom sector, Different complaints are for wrong billing, low service quality, no rendering of contracted service, unsatisfactory resolution of customer grievance etc. Although TRAI does not consider individual complaints, telecom operators have adhered to TRAI regulations related to consumer redressal. TRAI have laid down certain conditions for adhering and maintaining quality of services. Consumers can register their complaints to TSPs via SMS, email, call centres etc. Analysis of many guidelines, regulations shows that they origin from complaints received by consumers to authority, so consumer complaints also assist to judge performance of sector and so authority designs guidelines and measures to ultimately achieve consumer satisfaction.

To increase awareness of consumers about grievance handling TRAI publishes consumer handbook having gist from consumer point of view for all the regulations, directions, measures, starting from enrolment as telecom consumer and everything related to telecom consumers (Telecom Regulatory Authority of India, 2017). It is expected that consumer complaints and public grievances are resolved in stipulated time, in efficient and cost-effective way through an easily accessible system

\section{EXISTING COMPLAINT REDRESSAL SYSTEM \& RESULTS}

Primary responsibility of resolving consumer complaints generally lies with telecom service provider (TSP) and not with TRAI though TRAI has designed measures to protect interests of consumers via specification of broad framework for complaint resolution mechanism by TSPs. It also monitors from time to time for its effective implementation along with its public outreach programs.

Consumer protection and grievance redressal regulation was first issued in 2007 which was three-tier architecture for grievance resolution. To make this architecture more effective and increasing awareness about it in consumers was important aspect of this regulation. Necessary changes were made in this regard and consumer complaint redressal regulation 2012 was issued by TRAI after getting suggestions from stakeholders. It included a mechanism of two-tier for more efficient and swift resolution process. This system has been in place for more than 6 years.
Table-I: Two-tier framework for complaint redressal

\begin{tabular}{|l|l|}
\hline Tier & Mechanism \\
\hline Tirst & $\begin{array}{l}\text { Complaint centre set up by TSP is the first } \\
\text { stage of complaint redressal. It has a toll-free } \\
\text { consumer care number. The complaint } \\
\text { Centre is accessible to consumers through } \\
\text { this number, through email or post. If } \\
\text { consumer has complaint, he/she can } \\
\text { approach to this complaint centre. Complaint } \\
\text { centre will allocate a docket number to } \\
\text { complaint and date, time of complaint } \\
\text { registration, time limit of resolution of } \\
\text { complaint is mentioned and SMS is sent to } \\
\text { consumer. IVRS is used at complaint centre } \\
\text { with specific steps vis language selection, } \\
\text { selection of broad categories of complaints, } \\
\text { option to speak with customer care agent. }\end{array}$ \\
\hline Second \\
Tier & $\begin{array}{l}\text { If consumer is not satisfied with resolution of } \\
\text { his/her complaint or if complaint remains } \\
\text { unaddressed in first stage, consumer can } \\
\text { approach appellate authority (AA) } \\
\text { established by TSP. There is no fee for filing } \\
\text { of appeal. There is advisory committee to } \\
\text { appellate authority with two members, one } \\
\text { member from service provider and one } \\
\text { member from CAG registered with TRAI. } \\
\text { Every service provider must set web-based } \\
\text { complaint monitoring system and consumer } \\
\text { can track status of his/her complaint. }\end{array}$ \\
\hline
\end{tabular}

Total no. of complaints registered depends upon the no of subscribers. However, no. of appeals filed vis-à-vis complaints received throws a lot of variation amongst operators. This indicates disparity in implementation of redressal mechanism by TSPs. Further consumers had raised dissatisfaction with TRAI about accessing of redressal system particularly, very limited transparency in the appeal resolution, huge amount of time consumed for complaint resolution and quality of resolution. Sub-par performance of TSP managed redressal mechanism has also led to consumer grievances are sent to TRAI and Department of Telecom (DoT) by individuals.

Table-II: Complaints handled TSPs in 2 quarters

(Source: TSPs submission to TRAI)

\begin{tabular}{|l|l|l|}
\hline \multirow{2}{*}{ Operator } & \multicolumn{2}{|l|}{ Complaints in last two quarters } \\
\cline { 2 - 3 } & December 2015 & March 2016 \\
\hline $\begin{array}{l}\text { Bharati } \\
\text { Airtel }\end{array}$ & $\mathbf{3 2 0 9 4 5 0}$ & $\mathbf{3 8 8 9 7 9 9}$ \\
\hline $\begin{array}{l}\text { Idea- } \\
\text { Vodafone }\end{array}$ & 1077257 & 1062843 \\
\hline Reliance-Jio & $\mathbf{1 6 5 5 4 8 5}$ & 164494 \\
\hline
\end{tabular}


Table-III: Complaints handled by DoT and TRAI (Source: TRAI and DoT)

\begin{tabular}{|l|l|l|l|}
\hline \multirow{2}{*}{ Year } & \multicolumn{2}{|l|}{ No. of complaints received } & \multirow{2}{*}{ Total } \\
\cline { 2 - 3 } & DoT & TRAI & \\
\hline 2013 & 37202 & 20161 & $\mathbf{5 7 3 6 3}$ \\
\hline 2014 & $\mathbf{5 2 2 6 5}$ & $\mathbf{2 0 3 8 6}$ & $\mathbf{7 2 6 5 1}$ \\
\hline 2015 & $\mathbf{6 3 9 6 4}$ & $\mathbf{2 3 2 9 3}$ & $\mathbf{8 7 2 5 7}$ \\
\hline 2016 & $\mathbf{2 9 4 2 6}$ & $\mathbf{9 2 7 6}$ & $\mathbf{3 8 7 0 2}$ \\
\hline
\end{tabular}

\section{NEED FOR BETTER COMPLAINT REDRESSAL MECHANISM}

Though revised two-tier complaint redressal mechanism was in place for past 5-6 years, with the substantial growth in no of subscribers and a variety of service offered, the existing redressal mechanism was inadequate to address increasing no of complaints. TSPs receive more than a crore of individual complaints every quarter. Current system does not resolve complaints in timely manner and as it takes longer time for meager amounts, customers opt out eventually. This affects quality of service and its improvement. Below are the major points which indicate need to have better complaint resolution system:

- Though complaints received by TSP has a correlation to no of subscribers, the no of appeals or what gets referred to AA does not have correlation to no of complaints registered. This indicates that not all the systems set up by TSPs are similar or TSPs approach is similar towards resolution of complaint

- Time taken for redressal of complaints \& quality of response consumers are getting has been sub-par which led to individual consumers directly sending their complaints to authorities like TRAI/DoT. Further redressal of appeals and education in relations to the systems and procedures by TSPs has been below expectation.

- Issues of accessibility to and adequacy of redressal system is inciting dissatisfaction among consumers. Many complainants observe TSPs reluctance to refer complaint to AA despite the dissatisfaction in first stage of resolution. Thus, there is evident lack of transparency and consumer centric approach in the procedure.

In order to improve the complaint redressal mechanism, the regulator has approved a separate, a independent and a strong authority to resolve the public grievances very recently called as Telecom Ombudsman. This mechanism will be like ombudsman already existing in banking, insurance and electricity distribution sectors in the country. Internationally also, in telecom sector, there are established ombudsman in Australia and the UK which help resolve individual's disputes with TSPs. So, if a TSP does not resolve the consumer's complaint in time-bound manner $(8$ days), the consumer can file a complaint with telecom ombudsman for resolution (TRAI, 2019).

\section{DISCUSSION AND CONCLUSION}

There are different categories of complaints like billing complaints; call drops complaints, voice not clear complaints. Some complaints are technical, and some complaints are functional. If complaints are not resolved at first stage, then consumers can appeal to appellate authority for effective resolution of complaints. Core responsibility of resolution of individual complaints lies mainly with service provider. So, robust backend processes for effective resolution of complaints is very crucial for telecom customer's satisfaction.

Protection of consumers' interest is one of the key functions of TRAI. However, TRAI's current involvement in individual grievances redressal is very limited as TSPs are responsible to handle and resolve grievances. TRAI does not have any control over resolution method, time taken for resolution, and quality of response that consumers get and in terms of transparency of the redressal procedure along with resolution of appeals etc. An effective consumer redressal system could be a much-needed boon for many consumers and for improvement in quality of services.

TRAI has recently recommended a Telecom ombudsman and a three-staged resolution method with focus on latest technologies to resolve the complaints, the three stages in the proposed system are - resolution by TSP, resolution by Consumer Grievance Redressal Forum (CGRF) and eventually determination by Telecom Ombudsman.

Transparency, accountability and cost of redressal (manpower costs, penalties, reimbursements etc.) are key factors in deciding on the redressal system. Time taken for complaint redressal, consumer satisfaction and consumer retention etc. can be monitored to measure efficacy of system. A service provider is primarily responsible for satisfactory resolution of complaints and from ownership point of view a tangible performance can distinguish the service provider in fierce competition in Telecom market. Complaints should be categorized according to severity status. Each complaint can be tagged like High priority, Medium Priority and Low Priority and according to severity of complaint redressal mechanism procedure can be set. So effective and consumer redressal is needed as currently authority doesn't have adequate structure to handle consumer grievances efficiently for sector like Telecom.

This paper only refers to one specific country India and largely to only complaints registered. Paper focuses only on study of consumer redressal and its functioning however consumer satisfaction factors, antecedents of service quality of telecom these underlying factors are not considered in this paper.

Telecom Ombudsman was recently announced, exact structure in telecom sector and its impact assessment will be possible after a time period of 1-1.5 years and there lies the future scope for monitoring the impact of ombudsman on overall redressal system.

\section{REFERENCES}

1. Agyapong, G. K. . (2011). The Effect of Service Quality on Customer Satisfaction in the Utility Industry - A Case of Vodafone (Ghana). International Journal of Business and Management, 6(5) https://doi.org/10.5539/ijbm.v6n5p203

2. Akroush, M. N., \& Mahadin, B. K. (2019). An intervariable approach to customer satisfaction and loyalty in the internet service market. Internet Research. 
https://doi.org/10.1108/IntR-12-2017-0514

3. Hou, L. (2015). When competition law meets telecom regulation: The Chinese context. Computer Law and Security Review, 31(5), 689-700. https://doi.org/10.1016/j.clsr.2015.07.007

4. Kaur, H., \& Soch, H. (2018). Satisfaction, trust and loyalty: investigating the mediating effects of commitment, switching costs and corporate image. Journal of Asia Business Studies, 12(4), 361-380. https://doi.org/10.1108/JABS-08-2015-0119

5. Lai, F., Griffin, M., \& Babin, B. J. (2009). How quality, value, image, and satisfaction create loyalty at a Chinese telecom. Journal of Business Research, 62(10), 980-986. https://doi.org/10.1016/j.jbusres.2008.10.015

6. Ndukwe, E. (2011). The Telecommunication Revolution in Nigeria. (December), 1-21.

7. Oliver, R. (1981). Measurement and Evaluation of the Satisfaction Process in a retail Setting. Journal of Retailing, 57(Fall), 25-48. https://doi.org/10.6007/ijarbss.v1i2.35

8. Prasad, R. U. S. (2008). Dispute Resolution Mechanisms in the Telecom Sector : Relating International Practices to Indian. In Stanford Center for International Development.

9. Qayyum, A., ba Khang, do, \& Krairit, D. (2013). An analysis of the antecedents of loyalty and the moderating role of customer demographics in an emerging mobile phone industry. International Journal of Emerging Markets, 8(4), 373-391. https://doi.org/10.1108/IJoEM02-2011-0019

10. Telecom Regulatory Authority of India. (2017). TELECOM REGULATORY AUTHORITY OF INDIA NOTIFICATION. Notification, 1-67.

11. Telecom Regulatory Authority of India. (2018). TELECOM REGULATORY AUTHORITY OF INDIA NOTIFICATION.

12. TRAI. (2019). Telecom Regulatory Authority of India. Retrieved May 22, 2019, from https://main.trai.gov.in/consumer-

info/telecom/grievance-redressal-mechanism

13. Upadhyaya, R. C., \& Sharma, V. (2012). a Comparative Study of Telecommunication Service Providers BSNL and Airtel Operating in Gwalior Division India. International Journal of Business Management \& Research, 2(4), 2249-6920.

14. Wang, Y., Lo, H.-P., \& Yang, Y. (2004). An Integrated Framework for service quality, customer value, satisfaction: Evidence from China's Telecommunication Industry. Information Systems Frontiers, 6(4), 325-340. https://doi.org/10.1023/B

\section{AUTHORS PROFILE}

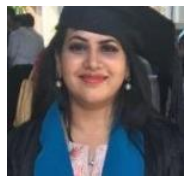

Ms. Mugdha Mujumdar is a $\mathrm{Ph}$. D. research scholar at Symbiosis International (Deemed University). She is working as Research Associate at Symbiosis Institute of Telecom Management. Her area of research interest are telecom policies, telecom governance, and customer grievance management.

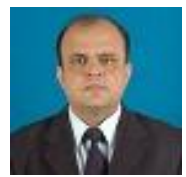

Dr. Sandeep Prabhu is working as Associate Professor at Symbiosis Institute of Telecom management, a constituent of Symbiosis International (Deemed University). $\mathrm{He}$ is $\mathrm{Ph} . \mathrm{D}$ is Marketing Management from Pune University (SPPU). His area of research interest are service quality management, customer experience management, and technology management.

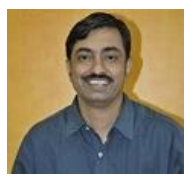

Dr. Giri Hallur working as Associate Professor at Symbiosis Institute of Telecom management, a constituent of Symbiosis International (Deemed University) $\mathrm{He}$ is an esteemed Deputy Director of institute. $\mathrm{He}$ is $\mathrm{Ph} . \mathrm{D}$ is Telecom Management from Symbiosis International (Deemed University). His area of research interest are telecom management, telecom and IT governance, and telecom technologies. 